\title{
Restraining the Exercise of Corporate Statutory Powers
}

\author{
Peter Jaffey*
}

\section{INTRODUCTION}

Much recent debate on company law has concerned the issue of contractual freedom: to what extent should the rights and duties of the shareholders and the directors inter $s e$, in the memorandum and articles and in other contracts betwen them, be a matter to be determined by agreement between the parties, rather than being stipulated by law? When should company law merely provide "default" or "background" terms and when "mandatory" terms"? Where no mandatory term applies, it is also necessary to consider what provision should govern alteration of terms. Alteration will often be desirable, but to require the consent of all the shareholders may not be practicable; on the other hand to allow alteration without unanimous consent creates the possibility that an alteration may be made that, without any quid pro quo, adversely affects a shareholder's interests².

Under the Companies Act 1985 (and previous Acts), the alteration of provisions of the memorandum and articles is governed by a number of "statutory empowering provisions", which confer powers on the company to effect particular alterations. These include s.9, which provides for alterations of the articles by special resolution, $\mathrm{s.4}$, which provides for alteration of the objects by special resolution, $\mathrm{s} .121$, which provides for alteration of the company's share capital by ordinary resolution, and s.135, which provides for a power to reduce share capital by special resolution. How are these statutory provisions to be understood? To what extent are they to be interpreted as mandatory provisions, which invalidate a provision purporting to exclude or modify the power, rather than default provisions, which leave it open to shareholders to reach different arrangements governing the alteration of provisions of the memorandum and articles? This issue, and in particular the validity of various types of restriction on the exercise of a statutory power, is the main subject of this article.

* Department of Law, Brunel University. I am grateful to Chris Ridley, Len Sealy, Fiona Padfield, Loraine Watson and Brian Davenport for their comments on a draft of this article.

1. A default term is a term that applies subject to contrary agreement, like provisions in Table A (see

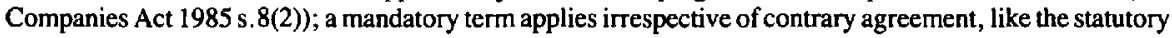
provisions imposing directors' duties. See Eisenberg (1989) 89 Colum. L. Rev. 1461 at 1463. The different positions on the debate on freedom of contract are summarised in Bebchuk (1989) Colum. L. Rev. 1395; and see generally the November 1989 issue of the Columbia Law Review. See also Riley (1992) 55 M.L.R. 782. 2. Or at least denies a shareholder the right to judge for himself whether the alteration is against his interests. 
A provision purporting to override or modify a statutory empowering provision might arise in a variety of forms. First, it might appear in the memorandum or articles themselves. A provision of the memorandum or articles might purport directly to exclude the power, or to modify it, for example by providing that an ordinary resolution rather than a special resolution is sufficient for the exercise of the power; or the memorandum or articles might confer a class right on one or more shareholders, purporting to make a provision of the memorandum or articles immutable except in accordance with the agreement of the class; or the articles might purport to allocate "weighted voting rights" in respect of the power so as to give particular shareholders effective control over its exercise. Secondly, a provision purporting to override or constrain the exercise of the power might appear in an extrinsic shareholders' agreement between some or all of the shareholders restricting the shareholders' freedom to vote on a resolution to exercise the power. Thirdly, such a provision might appear in the form of a contractual undertaking by the company not to exercise the power, and such an undertaking might be in a contract with a shareholder, or with an outsider.

Some of these issues were at stake in the recent and much discussed case of Russell v. Northern Rank ${ }^{3}$. In Russell, the issues were whether a shareholders' agreement was invalid if it purported to prohibit the shareholders from voting on a resolution to exercise the statutory power to increase share capital under s.1214, and whether an agreement by the company itself was invalid if it purported to prohibit the company in general meeting from exercising the power under $\mathrm{s} .121^{5}$. Thus the question was whether s.121 was mandatory, although the House of Lords did not express it in this way. In this article most of the discussion will relate to s.9, which is treated as analogous to $s .121$ and the other provisions conferring powers of alteration. On the other hand, as will be considered below, s. 303 of the Companies Act 1985, which confers on the general meeting a power to remove a director by ordinary resolution, is quite different from the provisions concerning alteration, although some discussion of these provisions appears to have relied on an analogy with it.

\section{INTERPRETING THE STATUTORY EMPOWERING PROVISIONS}

\section{Three interpretations of the statutory empowering provisions}

The statutory empowering provisions could, first, be interpreted as mandatory. On this basis they are designed to prescribe a certain appropriate degree of flexibility for the alteration of the terms of the memorandum or articles, preventing the shareholders from excluding change altogether, and at the same time preventing them

3. [1992] 1 W.L.R. 588, [1992] 3 All E.R. 161. The notes and articles on Russell v. Northern Bank include Riley [1993] N.I.L.Q. 34. Shapira (1993) 109 LQR 109, Savirimuthu (1993) 14 Co Law 137, Sealy [1992] C.L.J. 437, Davenport [1993] L.Q.R. 553, Ferran [1994] C.L.J. 343.

4. In fact the relevant provision in Northern Ireland was Art. 131 of the Companies (Northern Ireland) Order 1986, which corresponds exactly to s.121.

5. Davenport, above note 3, at p.557, argues that strictly only the first issue was before the House, because on the second issue the parties were agreed on the law; cf Ferran, above note 3, pp.348-350. 
from providing for change to be too readily effected by contrary agreement in the memorandum and articles or by extrinsic agreement. On this interpretation, the terms of the articles or extrinsic agreements involving the shareholders or the company are invalid if they have the effect of excluding or in some way qualifying the arrangements for alteration set down in the statutory empowering provision.

Secondly, a statutory empowering provision might be understood as "enabling"' 6 in the sense that it is intended to give the company a power that, it is presumed", the shareholders would not or might not otherwise have been able to create simply by agreement embodied in the memorandum or articles, but not to stipulate how the power should be controlled. If a statutory empowering provision is enabling in this sense, it does not frustrate its purpose to treat it entirely as a default provision, subject to contrary agreement between the shareholders, either in the memorandum or articles or in an extrinsic agreement. Thirdly, a statutory empowering provision might be understood as principally enabling, but mandatory only to the limited extent that it is designed to prevent shareholders from making it any easier to exercise the power, but without precluding arrangements designed to exclude the power or restrict its exercise or give particular shareholders a veto or greater influence to prevent its exercise. This article will be concerned only with restrictions on the exercise of statutory powers, and so for the most part it will not be necessary to distinguish between the second and third interpretations.

\section{Which is the best interpretation?}

The mandatory interpretation is perhaps ostensibly the most apt. In a couple of early cases concerning provisions in the articles purporting directly to override the statutory power of alteration, the judges assumed without discussion that this interpretation was correct. In Walker v. London Tramways ${ }^{9}$ the articles contained a provision purporting to make a certain provision of the articles unalterable. In a judgement reported in five lines, Jessel M.R. simply stated that "no company could contract itself out of [the statutory empowering provision] ". Similarly, in Ayre v. Skelsey's Adamant Cement Company ${ }^{10}$, Kekwich J. held that a provision of the articles purporting to require a four-fifths majority for a resolution to alter the articles was ineffective in ousting the statutory provision, and the company could still alter

6. The expression is used in Eisenberg (1989) 89 Colum. L.R. 1461, but not in quite the same sense.

7. Why this might be presumed will be considered in the next section below.

8. For example, by allowing for alteration by ordinary resolution rather than special resolution, or by giving control over the power to particular shareholders or even to the directors. "Easier" is vague, but it is not necessary to pursue the issue here.

9. (1879) $12 \mathrm{Ch}, \mathrm{D}, 705$.

10. (1905) 20 T.L.R. 587. 
the articles in the normal way by a special resolution with a three-quarters majority" ${ }^{11}$ However in none of the cases was there any discussion of the purpose of the statutory provisions concerning alteration, or any recognition of the possibility that they might be enabling.

To the modern eye, it appears that a statutory empowering provision that is purely enabling is superfluous. Under the modern approach company law is regarded as a regime that merely recognises the company as a separate entity whose members may have limited liability, and creates the framework for a set of terms to be agreed between the shareholders, subject to certain overriding mandatory terms if necessary to protect particular interests of shareholders or others ${ }^{12}$. On this approach a statutory empowering provision seems to be unnecessary if it is not intended to be mandatory. But the nineteenth century context in which the provisions were originally enacted can possibly explain why the provisions may have been intended as enabling.

Before the introduction of registered companies, incorporation was achieved only through an Act of Parliament or by the exercise of the royal prerogative, and under the rather nebulous concession or privilege theory a body so incorporated appears to have been understood as a sort of quasi-governmental body or emanation of the state, whose constitution was a matter to be determined by Parliament or the Crown in the public interest rather than by the private agreement of the participants in the venture $^{13}$. This was appropriate for bodies that exercised quasi-governmental

11. Like Jessel M.R. Kekwich J. regarded the special provision for alteration as a " [regulation] which attempted to evade the provisions of the statute", and the proposition that it was invalid was "so directly conformable to first principles that it really required no elucidation". He also relied in part on Re Peveril Gold Mines Ltd ([1898] 1 Ch. 122), but in this case the issue was not whether an article could be made unalterable, but whether the company could by a provision of the articles exclude the shareholder's right under the statute to apply for winding up. The court suggested that the statutory provision was mandatory because it was for the protection of shareholders and that a shareholder should be protected against "an attempt to remove a statutory safeguard of the inexperienced intending shareholder": $[1898] 1 \mathrm{Ch} .122$ at 126, per Byrne J, approved by the Court of Appeal. See also the more recent case of Bushell v. Faith, where Russell L.J. said, obiter, in the Court of Appeal: "An article in terms providing that no alteration shall be made without the consent of " $X$ " is contrary to [s.9] and ineffective. . " There is another line of cases (including Russell v. Northern Bank) which are concerned with the effect of a statutory empowering provision on extrinsic contracts by the company purporting to exclude or restrict the exercise of the statutory power, where the same assumption seems to have been made. These will be considered below. 12. And with provision for default rules to apply in the absence of agreement. This approach may be referred to as the nexus of contacts approach, in contradistinction to the concession or privilege approach considered below.

13. For recent discussion of the nexus of contracts approach and the concession approach, see Parkinson, Corporate Power and Responsibility (Clarendon, 1993) p.25; Stokes, "Company Law and Legal Theory", in Legal Theory and the Common Law, ed. Twining (1986); Easterbrook \& Fischel, The Structure of Corporate Law (Harvard University Press, 1991) pp.8-22. See also Formoy, The Historical Foundations of Modern Company Law (Sweet \& Maxwell, 1923) p.57. And with particular reference to the issue discussed here, see Riley, above note 3, at p.42. The distinction adopted in the text is that the nexus of contracts approach presupposes that the law is designed to promote or protect the private interests of the human participants in the company subject to specific rules to protect other interests, including in some respects the public interest, whereas the concession theory presupposes that the company is a public body in the administrative law sense and that company law is designed generally directly to promote the public interest. 
functions like the regulation of trade or the administration of foreign territory. When incorporation began to become readily available to entirely private undertakings, it appears initially still to have been considered necessary that the state should examine and approve the purpose of the undertaking and the terms on which it was to be carried on $^{14}$.

The statutory power to alter the aticles by special resolution appears to be derived from provisions in the same form in the deeds of settlement of unincorporated joint stock companies ${ }^{15}$. In a deed of settlement, under the general law of contract, there was no restriction on the terms that could be agreed between the parties concerning alteration. The first Companies Act of 1844 , which conferred legal personality on a deed of settlement company once its deed had been submitted to the Registrar of Joint Stock Companies, simply imposed a requirement of notification to the Registrar of any alteration of the articles" 16 . But the Companies Act 1856, which was "the first to introduce companies constituted in the modern manner by memorandum and articles of association" 17 , included a provision in the modern form providing for alteration of the articles by special resolution ${ }^{18}$. Why should this Act, which was designed to facilitate the formation and operation of the existing, and well-established, joint stock

This distinction is sufficient for the argument in the text and appears to reflect the way in which the expression "nexus of contracts" is often used (although it may not do justice to the economic theory in the context of which the expression was devised, apparently by Jensen \& Meckling 3 J.Fin.Econ. 305 (1976): see the articles cited in note 1 above.). On this view the nexus of contracts theory is not inconsistent with the presence of mandatory terms to protect the private interests of paticipants in the company, or the public interest, although the expression has been particularly popularised by proponents of law and economics who tend to be averse to mandatory terms, at least to protect the interests of participants: see Bebchuk (1989) Colum.L.Rev. 1395 at 1408, and (1989) 102 Harv.L.Rev. 1820.

14. For example, Formoy, above note 13, at p.57, says in connection with the Letters Patent Act, which predated the registered companies legislation and was "intended to obviate the inconvenience and expense of applying to Parliament for a private Act . . ." by enabling an unincorporated company to sue and be sued in the company name, that "as all companies were compelled to apply to the Crown for letters patent a responsibility was in some degree thrown upon the advisors of the Crown, who, as the right of suing and being sued was taken to be a privilege, came to be considered as judging, in some degree, of the expediency of the undertaking". And Formoy quotes Bellenden Ker in the Report on the Law of Partnership, 1837, making the following suggestion: "[T] the powers to be granted in all charters and letters patent giving limited responsibility, \&c., should be clearly defined and set forth so that the several powers to be granted and all conditions as to registry and transfer of shares might be at once referred to in the letters patent or charters. This measure would leave to the advisors of the Crown merely the consideration of the expediency of granting the privilege sought without the inconvenience of considering in detail the effect of the different provision which parties had inserted in the drafts of their proposed charters; it would have the effect, also, of very materially abridging the length of the charters or letters patent. And, further, by the powers and provision being uniform, wherever it becomes necessary to submit them to judicial interpretation, the decisions of the Court would apply to the whole class, and would have the effect of forming a uniform system of construction applicable to all similar instruments." This view was presumably one of the reasons behind the model set of default articles. Ker's argument for mandatory terms is echoed, in the language of contemporary law and economics, in Gordon's "public good" hypothesis: (1989) 89 Colum.L.Rev. 1549 at 1567.

15. For a reference to such a provision, see Baily v. British Equitable Assurance Co [1904] 1 Ch. 374 at 375,384 .

16. S.10 Companies Act 1844.

17. Formoy, above note 13, p. 123

18. S.33 Companies Act 1856. 
company by conferring limited liability as well as separate personality, introduce a provision apparently imposing a term on shareholders in respect of a matter on which they had previously been free to reach their own agreement? On the concession approach, the draftsman might have considered, even if the notion that the terms on which the enterprise was to be carried on were to be officially evaluated had become a fiction, that alteration of the terms of the memorandum and articles as originally registered (and in theory approved) required an enabling statutory power, and that a provision in the memorandum or aticles themselves providing for alteration would be ineffective ${ }^{19}$.

If it were really appropriate to apply the concession theory, one would expect statutory provisions to be mandatory rather than default provisions, but one would not expect the shareholders to have a power of alteration to be exercised in their own interests. From the very start, however, the terms of the articles were a matter entirely for the shareholders to determine, and the philosophy expressed by Lord Watson in Welton v. Saffery appears to have taken hold: "The truth is, that all these ${ }^{20}$ are domestic matters, in which neither creditors nor the outside public have an interest, and with which, in my opinion, it is the policy of the Legislature not to interfere." 21 In the light of this approach it is appropriate to interpret a statutory empowering provision, which affects only the interests of the shareholders, as enabling ${ }^{22}$.

In the first full Companies Act of 1862, the position of the memorandum was very different from that of the articles. The provisions of the memorandum were incapable of being altered except in the respect that the share capital could be increased ${ }^{23}$. This may have been because, under the influence of the concession theory, it was considered that at least the characterising features of a registered company should not be open to alteration once they had been formally approved in the registration procedure ${ }^{24}$, or because it was considered necessary in order to protect specific interests of

19. If it was intended to have any mandatory effect, it seems most likely, in the light of the approach to the memorandum, which was made largely immutable, that it was intended to prevent excessively relaxed rather than excessively restrictive provisions for alteration i.e. the third interpretation mentioned above. If, in the absence of a statutory provision, there would be no power of alteration at all, it is a reasonable interpretation that a statutory provision for alteration by special resolution should be understood as a provision enabling the company to alter its articles either by special resolution or by any agreed procedure that is no less restrictive.

20. Lord Watson was referring to the distribution of surplus assets on a winding up.

21. [1897] A.C. 299 at 309.

22. Another possibility is that the statutory power to alter the articles was considered necessary, even though enabling, to qualify the other provisions of the statute that required a statement of the provisions of the articles without referring to any possibility that such provisions could be open to change. And Gower, Principles of Modern Company Law (5th ed., 1992) (referred to below as "Gower") at p.534, suggests that a power in the articles might have been regarded as ineffective, and a statutory provision necessary (as an enabling provision), on the ground that the relationship with a shareholder based on an issue of shares rather than original subscription might have been held to be governed not by the statutory contract but only by the separate terms of issue, and therefore not subject to alteration in accordance with a power in the articles. Nowadays a contract of issue of shares would be taken necessarily to incorporate the aticles; a contract failing to do so would not constitute the contractor a shareholder.

23. Joint Stock Companies Act 1862, s.12.

24. Gower, p.14. 
shareholders or creditors ${ }^{25}$. In either case, because of the original presumption against alteration, it is very easy to interpret statutory empowering provisions subsequently introduced, and the original provision for the increase of share capital in its context, as enabling provisions that were not designed to preclude contrary agreement, or at least contrary agreement to have a stricter rule for alteration. There is no reason why the introduction of a power of alteration previously withheld from shareholders should necessarily be understood to deny them the freedom to impose restrictions on its exercise if they so wish ${ }^{26}$.

\section{Weighted voting rights}

If a provision were intended to be purely enabling, one would expect it simply to confer the power on the company and leave it for the memorandum or articles to specify the conditions and procedure for its exercise. In fact the provisions generally require a special resolution of the general meeting. This may indicate a mandatory rationale or it may simply indicate that in pursuing an enabling rationale the draftsman overlooked the possibility that shareholders might wish to provide for a different arrangement for the exercise of the power, and simply assumed that shareholders would not in practice have any reason to depart from this standard form of the provision.

On the other hand if a provision is to be mandatory, one would expect it to be exhaustive, in the sense that it specifies completely the conditions for exercise of the power. In fact, in an important respect the provisions are apparently not exhaustive, since they do not expressly provide for the allocation of votes on the exercise of the power, and this leaves open the possibility of weighted voting rights that give particular

25. In Ashbury Railway Carriage and Iron Company v. Riche (1875) L.R. 7 H.L. 653, where the House of Lords established the ultra vires doctrine, the House was influenced by the fact that the objects clause was incapable of being altered. Although the House said that the immutability of the clause and the ultra vires doctrine were designed to protect the interests of existing shareholders and creditors of the company (per Lord Cairns L.C., at p.667, per Lord Hatherley at p.684, 687) in fact the speeches were more strongly influenced by the idea, attributable to the concession theory, that because the company owed its existence to the statute its inherent powers were necessarily limited to those expressly granted (per Lord Cairns L.C. at p.670, per Lord Chelmsford at p.678, per Lord Hatherley at p.686). Blackburn J., in a lower court in Ashbury (Law Rep. 9 Ex. 263, considered in the House of Lords at (1875) L.R. 7 H.L. 653 at 677,685 ), took the view that the objects clause did not limit the inherent full capacity of the company. His view appeared to be that the registered company was to be understood as a partnership or unincorporated joint stock company (having full contractual capacity) on which had been grafted a separate personality and limited liability, a view in keeping with the nexus of contracts rather than the concession approach. Blackburn J.'s view has eventually prevailed, following the latest reforms: see Companies Act 1985 s.35. With the rejection of the doctrinal impediment to alteration, and the recognition that the availability of a power of alteration will not prejudice shareholders and creditors, almost all the provisions of the memorandum are now capable of being altered, although, as a "relic of the time when . . . [ memoranda] were generally unalterable" (Gower, p.532) s.2(7) still provides that the memorandum may not be altered except as provided in the Act.

26. Ss. 121 and 135 are expressed to apply only "if . . . authorised by [the company's] articles". Thus the issue is whether a provision in the articles that purports to exclude the power or make it subject to additional restrictions is effective and whether the alteration of this provision can itself be precluded or made subject to restrictions, notwithstanding s.9. 
shareholders extra influence on the decision to exercise the power. One might argue that a certain allocation of voting rights should be taken as implicit in the statutory provisions: for example one vote per share, or votes in accordance with nominal share value. But the use of weighted voting rights is one of the means open to company draftsman to adjust the rights of participants in the company, and in the absence of express provision it is difficult to say that there is a standard allocation of voting rights that the statutory empowering provision my be taken to have implicitly prescribed ${ }^{27}$. This issue arose in Bushell v. Faith ${ }^{28}$, which concerned the statutory power to remove a director, now contained in $5.303^{29}$.

The statutory provision empowered the general meeting to remove a director by ordinary resolution "notwithstanding anything in [the company's] articles or in any agreement between [the company and the director]". The defendant had sought to secure his position as director, despite s.303, through a weighted voting provision that gave him three votes per share instead of one on a resolution to remove him under s.303. The issue was whether the weighted voting provision was effective on a resolution under s.303. The House of Lords held that the provision was effective, but the decision was bitterly criticised in some quarters ${ }^{30}$. Unlike the provisions for alteration of the memorandum and articles the statutory provision in s. 303 is evidently mandatory; it is expressed to override contrary agreement in a service contract and in the articles ${ }^{31}$, and it was clearly intended to abolish secure lifetime directorships. But s.303 is flawed (given its apparent objective) in not providing for voting rights on the exercise of the power. In the absence of express provision concerning voting rights the House of Lords considered itself bound to apply the usual rule that voting rights may be prescribed by the articles. This makes the statutory power merely a formal mechanism for removal, control over which may be manipulated by the articles. A provision for a mandatory power of removal should stipulate who is to control the power, and so should include provision for voting rights ${ }^{32}$. The comparison with

27. One might argue that as a matter of fairness there should be one vote per share, or that the number of votes per share should be proportional to the nominal value of the share. But, in theory at least, a prospective shareholder will value a share in the light of its voting and substantive rights, and so no injustice is done by an uneven allocation of voting rights. There is an argument of economic efficiency in favour of the number of votes being proportional to the financial interest conferred by the shares (reflected in the proposed Fifth EC Directive on Company Law (O.J. C240 9.9.83 p.2) which provides by Article 33 that voting rights shall normally be proportional to subscribed capital). On an issue for decision by shareholders the decision is most likely to promote the objective of maximising the company's profits overall if the influence of shareholders is proportional to their respective financial interests: see Easterbrook and Fischel, above note 13, p.73.

28. [1969] 1 All E.R. 1002.

29. The provision was actually in s.184 Companies Act 1948, but will be referred to as $s .303$.

30. See Schmitthoff [1970] J.B.L. 1.

31. It was not introduced as an enabling provision in the sense discussed above, because it was clearly possible, and no doubt generally the case, for the articles to provide for removal of a director, as is recognised in $s .303(5)$.

32. Bushell v. Faith appears to have involved a quasi-partnership company, where it is now accepted under the s.459 jurisdiction that a shareholder has a "legitimate expectation" to remain as a director: see below, text following note 99 . 
s.303 and Bushel v. Faith does not, however, cast much light on the interpretation of the statutory provisions concerning alteration. The case demonstrates that a mandatory provision ought to include provision for voting rights, but at the same time provides an example of a statutory provision clearly intended as mandatory but perversely drafted without such provision.

\section{Class rights}

It is clear that the statutory powers of alteration are subject to contrary provision where the articles provide for class rights. Under the present law, s.125 of the Companies Act $1985^{33}$ provides expressly that provisions of the memorandum or articles that confer class rights on a shareholder or class of shareholders may not be altered except in accordance with the statutory procedure, which is, generally speaking, the passing of a class resolution by a three-quarters majority (or in the case of a class of one person, the consent of that person). It appears to be a controversial matter whether, before $\mathrm{s} .125$ (or its statutory predecessors) was enacted, the statutory power of alteration of the articles was subject to the limitation that it could not be exercised so as to remove class rights - that is, whether or not the statutory empowering provision was mandatory in this respect. Gower's understanding of the position is consistent with the view that the statutory provision for alteration is subject to contrary provision. He says that class rights were previously immutable except in accordance with a provision in the articles for their alteration, and that the effect of $s .125$ was principally to create a power of alteration where the articles contained no such express provision ${ }^{34}$. However it was apparently a commonly held view that, before the introduction of s.125, class rights could be altered in the normal way by the exercise of the statutory power by the shareholders as a whole ${ }^{35}$. The view is difficult to accept, because the very existence of classes of shareholders - that is, shareholders with common interests in the company that differ from those of other shareholders

33. S.9 is expressed to be "[s]ubject to provisions of this Act".

34. Gower, p.535. Furthermore the provision for alteration in $\mathbf{s . 1 2 5}$ is expressly (subject to exceptions) a default rather than a mandatory provision, since by s.125(4) and (5), it expressly recognises the effectiveness of provisions in the articles that impose different requirements for alteration than the requirement of a class resolution passed by a three-quarters majority.

35. Ibid. The view is adopted in Farrar's Company Law (3rd ed., Butterworths) p. 230 (cited below as "Farrar"). 
- seems to be incompatible with class rights being subject to alteration by the whole body of shareholders ${ }^{36}{ }^{37}$.

Adopting the view attributed above to Gower, the recognition of class rights and the limitation they impose on the exercise of the statutory power of alteration, even before any such limitation was expressed in the statutory provision itself, is inconsistent with the interpretation of the statutory empowering provision as fully mandatory. Furthermore, one might argue that the recognition of class rights and the concomitant restriction on the statutory power should be taken to support a more general principle that the statutory power is always subject to contrary provision, and that class rights simply provide a case where the principle is applicable because of the readiness with which it may be inferred from the presence of class rights in the articles that the statutory power is not to be capable of being exercised in the normal way ${ }^{38} 39$.

One may conclude that it is far from clear that the statutory empowering provisions

36. In Cumbrian Newspapers v. Cumberland and Westmoreland Herald ([1987] 1. Ch.1), Scott J. took the view that before $s .125$ was introduced, class rights could be altered by the exercise of the statutory power by the shareholders as a whole in the normal way, except where there was a provision for alteration, where the provision had to be followed. But, with respect, his arguments are unconvincing. First, Scott $J$. said that the view that class rights were immutable except in accordance with a provision for alteration in the articles was rejected in Andrews v. Gas Meter ([1897] $1 \mathrm{Ch} .361$ ). But this case is usually taken to stand for the proposition that where the share capital clause of the memorandum makes no explicit reference to more than one class of shares if it is not to be inferred that the clause precludes the creation of another class, so that a new class can be created if authorised by the articles. The case can be taken to hold that a class right of shareholders against the creation of a new class of shares will not be implied in the memorandum or articles, which says nothing about how such a right might be altered if it existed: cf cases like White v. Bristol Aeroplane ([1953] Ch.65), which hold, in effect, that no class right will be implied against the issue of bonus shares, or to pre-emption rights, so as to preserve the present proportion of votes of a class of shareholders. Secondly, Scott J, relied on the assumption that the statutory power of alteration is mandatory, and so could not be limited except by statutory provision. This was taken to be the case without discussion, and is difficult to reconcile with the judge's conclusion that the statutory empowering provision had always been subject to contrary provision in the case where there was an express alteration clause, although not to contrary provision clearly implicit in the presence of class rights in the articles: see at [1987] 1 Ch. 1 at 21 , and Gower, note 21 on page 535.

37. In Allen v. Gold Reefs [1900-3] All E.R. Rep. 746, the Court of Appeal accepted that the statutory power of alteration could be displaced by a "special bargain" with a particular shareholder: see per Linley M.R. at p.748, per Romer L.J. at p.754. It is not entirely clear whether the judges had in mind an extrinsic special bargain incorporated in the articles. In either case, the effect would be to preclude the exercise of the statutory power of alteration.

38. On the other hand one might infer that the general principle is that no restriction on the exercise of a statutory power can be effective except to protect a class right. The effect would be that restrictions on alteration could exist only in the form of a veto exercised collectively by shareholders with the same interests, and that a shareholder could never protect himself from the collective decision of shareholders having the same interests as him. This might be defended as the best way to preserve flexibility in alteration whilst at the same time allowing for essential protection. This cannot be inferred, however, from the statutory empowering provision itself. S. 17 of the Companies Act 1985 provides for the entrenchment in the memorandum of a provision whether or not it creates a class right.

39. The difficulty, where shareholders have divergent interests, is to determine to what extent it was intended that the interests should be subject to protection as class rights, as opposed to being subject to alteration by special resolution of all the shareholders. 
are mandatory, or that they are frustrated by provisions in the memorandum or articles that restrict their exercise. Although there are certainly examples of cases where the judges have assumed that they are mandatory, a consideration of class rights and weighted voting rights and of the context in which the provisions were introduced provides support for construing them as enabling and subject to contrary provision. Certainly it may be argued in the light of the modern conception of company law as a framework for private arrangement subject to mandatory rules only where necessary to protect specific interests, either of outsiders or shareholders, that the statutory empowering provision should not be construed as mandatory in the absence of any good reason to suppose that, either originally or in a more recent enactment, they were based on a deliberate judgement that unfairness or inefficiency would result from leaving the matter for agreement between the shareholders. Although shareholders are likely to want to have a provision for alteration that does not rely on the consent of every shareholder, they may reasonably want a particularly restrictive procedure for alteration, at least in relation to certain provisions ${ }^{40}$, and there seems no good reason to deny them the freedom to agree on such restrictions (even if it is necessary, in their own interests, to deny them the freedom to agree on arrangements for alteration that are more flexible than might be considered prudent).

\section{SHAREHOLDERS' AGREEMENT RESTRICTING THE EXERCISE OF A STATUTORY POWER}

The question whether the statutory empowering provision in $\mathrm{s.121}$ is mandatory was in issue in Russell v. Northern Bank. Lord Jauncey held that an extrinsic shareholders' agreement binding the shareholders not to vote to exercise the power was not inconsistent with the statutory empowering provision. Some commentators have asserted trenchantly that the statutory empowering provisions are mandatory, and therefore that the decision in Russell "[prevents] the application of mandatory provisions of the Companies Acts" 41 . But Lord Jauncey's decision, although not

40. Bebchuk (1989) 89 Colum.L.Rev. 1395 at 1401. Denying that a mandatory provision should apply to govern a particular issue does not amount to saying that it should not be possible for the courts to intervene to override the terms of the articles, particularly if circumstances have changed. See Riley, above note 1, p. 47 .

41. Shapiro, above note 3 , at p.213. Savirimuthu, above note 3 , at p. 139 goes so far as to say that the House of Lords "expressly overrode statute" and thereby "usurped the function of the legislature". 
made with any explicit discussion of whether the statutory empowering provision was enabling or mandatory, ${ }^{42}$ is at least consistent with the conclusion above ${ }^{43}$.

\section{Unfair prejudice}

There is a more plausible argument against the enforceability of shareholders' agreements that restrict voting freedom based not on a supposed inconsistency with a statutory empowering provision, but on the notion of unfair prejudice or minority oppression. For example, it has been suggested ${ }^{44}$ that each shareholder should be "entitled to assume that all other members will exercise an independent judgement upon those issues on which their votes are cast", and that a shareholder may have a remedy for unfair prejudice under s.459 of the Companies Act 1985 if another shareholder's vote is instead governed by a contractual restriction on voting ${ }^{45}$. The orthodox view is that shareholders are not fiduciaries for the company or each other, and are not obliged to vote in such a way as to promote the company's business or the interests of the generality of shareholders, but are free to exercise their votes in their own interests, and to bind themselves by contract as to the exercise of their

42. The effect of the statutory empowering provision on an agreement by the company itself will be considered separately below. The decision in Russell with regard to the shareholders' agreement appears to have been based mainly on the principle that, as a general rule, a share is the shareholder's property for him to dispose of as he wishes, citing Welton v. Saffery [1897] A.C. 299 at 331. (See also Pender v. Lushington (1877) 6 Ch. D. 70 and North-West Transportation Co v. Beatty (1877) 12 App.Cas.589.) It is no doubt appropriate for certain purposes to regard a share as an item of property, in the same way that a right under a contract can sometimes be regarded as an item of property. However property rights can be subject to inherent limitations, and although the conclusion that a share is the shareholder's property can be understood to exclude the possibility that the shareholder is a fiduciary for the company or other shareholders, it does not indicate what rights are actually attached to a share, or what specific restrictions may exist on the exercise of rights prima facie conferred by ownership of it.

43. Another argument against allowing extrinsic shareholders agreements, and against agreements by the company that restrict the exercise of powers in the general meeting, is that potential shareholders and other interested parties have no way of knowing whether such agreements exist or what their terms are, whereas they have access to the terms of the memorandum and articles through the Register. However this difficulty can be dealt with sufficiently by a requirement of registration of such agreement or notice to interested parties, if it is not sufficient to leave the matter to negotiation. See Riley, above note 3, p.48. 44. Riley, above note 3, p. 46 .

45. The suggested stipulation that shareholders must exercise an independent judgement is reminiscent of the law concerning public powers. (I do not mean to attribute this interpretation to Riley.) Where a person or a body of people have vested in them by statute a public power - that is, a power to be exercised in the public interest - it is a long established principle of administrative law that a contract by which the person or a member of the body purports to bind himself as to how the power is to be exercised is unenforceable: see for example Ayr Harbour Trustees v. Oswald (1883) 8 App.Cas. 323. The statute requires the discretion to be exercised by the person or body in whom it has been vested in the light of prevailing circumstances, and a prior fettering by contract of that person's discretion, or the discretion of members of the body, or a surrendering of the discretion, is incompatible with the empowering statute. The reference in Russell to the "fettering" of "statutory powers" ([1992] 3 All E.R. 161 at 168 per Lord Jauncey) adopts the language of administrative law. The same principles apply to fiduciaries (including company directors) taking decisions in the interests of other people. But, unless the concession theory of incorporation is adopted, it is not the rationale of company law to confer powers on the general meeting to be exercised in the public interest, or the interests of other parties than the shareholders themselves; it is to establish a framework for the pursuit of the interests of the shareholders, subject where appropriate to mandatory restrictions to protect shareholders or outsiders. See note 42 above. 
votes, subject only to rather ill-defined rules to protect against minority exploitation ${ }^{46}$.

It is a controversial and confused question what general principle of unfair prejudice or minority oppression (if any) determines when an exercise of a statutory power in the general meeting, or any other power of the general meeting, is ineffective $e^{47}$. There is a line of cases concerned with limits on the freedom of shareholders to pass a resolution altering the memorandum or articles where the alteration would be unfair to a minority shareholder. The rule is stated to be that an alteration is ineffective if it is not "bona fide for the benefit of the company as a whole", although exactly how this phrase is to be understood is a matter of controversy ${ }^{48}$. Nowadays the issue is likely to be dealt with under the rubric of unfair prejudice under s.459.

The issue raised here is whether it can be a form of minority oppression or unfair prejudice to one shareholder for another shareholder to be subject to a contractual restriction on his voting on the exercise of the power. It is difficult to see why, as a general rule, a shareholder who was actually party to a shareholders' agreement that imposed voting restrictions should be able to complain that it is unfair prejudice for other shareholders to vote in accordance with the agreement or to insist on its observance. As in Russell, protection of a minority shareholder will, to the contrary, generally require enforcement of the agreement ${ }^{49}$. However the position may be different in the case where a shareholder complains of unfair prejudice arising from voting restrictions in a shareholders' agreement to which he is not party - because he is a new shareholder, for example, or because the shareholders' agreement was not entered into by all the shareholders. In such a case a shareholder who voted in accordance with the agreement would not be able to claim that the complainant had (presumptively in his own interest) agreed to the restrictions. Is it then unfair to the complainant for the voting of other shareholders to be dictated by a contract?

One approach to the question might run as follows. Arrangements in the memorandum or articles, or in the statute, for certain issues to be settled by vote are necessitated by the impossibility of foreseeing all the contingencies that may arise in the life of the company, and making provision for them in the initial terms of the

46. See note 42 above. However because the relationship enshrined in a company is likely to be long term, there are strong arguments for the court to have a jurisdiction to override arrangements in cases where there has been a change of circumstances over a long period: see Riley, above note 3 at p.47. Such an argument might be addressed under s.459. In some jurisdictions in the U.S., shareholders' agreements are limited to a specified tenn: see Easterbrook \& Fischel, above note 13, p.131, and Eisenberg, above note 1 , at p. 1466 . See also Riley, above note 1 , at p. 786 .

47. The approach below makes no distinction between voting under a statutory power and voting to exercise powers that may be conferred on the general meeting by the articles directly, like the power to issue shares, as in Clemens v. Clemens ([1976] 2 Al E.R. 268). This seems quite appropriate, since there seems to be no reason to distinguish between the two. In both cases, there is a power capable of being exercised by a majority and capable of operating unfairly at the expense of a minority: see per Lindley L.J., in Allen v. Gold Reefs of West Africa [1900] 1 Ch.656 at 659.

48. Allen v. Gold Reefs of West Africa [1900] 1 Ch.656; Greenhalgh v. Arderne Cinemas [1951] Ch. 286. 49. In Russell, the plaintiff had entered into an agreement precluding further share issues to protect his minority interest in the company. 
company's memorandum and articles ${ }^{50}$. If, on joining the company, shareholders may be taken to have agreed, for this reason, to postpone decision on certain matters and provide for them to be settled by vote when they arise, it would be reasonable to impose such restrictions on the voting as it would be reasonable for each shareholder to insist on at the time of joining, to protect himself against a resolution that might operate unfairly against him ${ }^{51}$. It would be reasonable to suppose that a shareholder in that position would be prepared to accept that on a matter that might affect him adversely a decision should be made by vote amongst only those shareholders who will be affected by the vote in the same way. The shareholder then risks only being outvoted on matters in which his judgement differs from other shareholders, and not on matters where other shareholders have different interests and incentives at stake. This is the basis for class rights, where shareholders with common interests have the right as a class to determine whether their rights should be altered ${ }^{52}$. It also supports the rule that on a resolution on a class vote a shareholder may not vote if he has an interest in the outcome other than as a member of the class ${ }^{53}$.

One might argue that a shareholder who is not himself party to a voting agreement could complain that such an agreement gives a shareholder who is party to it an interest in the vote otherwise than as a shareholder, for the purpose of the principle above. But whether this is the case would depend on the nature of the agreement. Arguably it would not offend against the principle if all the parties to the agreement were shareholders and the only benefit from the agreement for each party was the effect of the agreement on the shareholder's interest in the company. Here each shareholder would simply have sacrificed his freedom to judge how to promote his interest as a shareholder in the short term, for the sake of promoting that interest in the long term, and not for the pursuit of an extraneous interest. On the other hand it might offend against the principle if a shareholder were restricted by an agreement by which he had sacrificed his interest as a shareholder to some extent in return for an extraneous benefit, for example under a commercial agreement with an outsider, or under an agreement with other shareholders to secure a directorship. In such a case a shareholder not party to the agreement might be able to claim that it is unfair prejudice under s. 459 for another shareholder's voting decision to be governed by the agreement, and consequently that the agreement should not be enforceable by injunction.

50. See Easterbrook \& Fischel, above note 13, at p.67.

51. This is an exercise in generating default rules by "hypothetical contracting": see for example Riley, note 1 above, at p.788.

52. See the discussion above under the heading "class rights".

53. British America Nickel Corpn Lid v. O'Brien [1927] A.C. 369. However it has not generally been accepted that the presence of an extraneous interest disables a shareholder from voting, for example where he has a personal interest as an outsider dealing with the company. Furthermore, it is not easy to say what factors should be taken into account in determining whether shareholders are in a different position or have different interests. 


\section{AGREEMENT BY THE COMPANY ITSELF NOT TO EXERCISE A STATUTORY POWER}

This section deals with the case of an agreement by the company itself that purports to restrict the exercise of a statutory power. In Russell, the company itself was party to the shareholders' agreement, and it was held, relying on a line of cases considered below, that the company's undertaking was unlawful, on the ground that the company could not deprive itself of a statutory power ${ }^{54}$. Thus, in this context, the statutory empowering provision was treated as mandatory in the sense described above. Davenport has pointed out that this can create practical problems for companies, since restrictions on the exercise of a statutory power by agreement with third parties are an important means of providing security to outsiders contracting with a company in certain types of contract, in particular loan contracts 55 .

The finding that the statutory empowering provision was mandatory in this respect does not sit easily with the other aspect of the decision in Russell, that the statutory empowering provision did not prohibit voting restrictions in shareholder agreements. It is not clear why the statute should be understood as mandatory for one purpose but not the other ${ }^{56}$. If the statute does not stop shareholders from imposing restrictions on the exercise of power, why should it stop the company from accepting such a restriction if it is accepted in accordance with the company's constitution ${ }^{57}$ ?

54. As mentioned above, note 5, Davenport has argued that this part of the decision in Russell is not part of the ratio of the case.

55. Davenport [1993] L.Q.R. 553. Davenport says (at p.553) that such provisions "are regarded as essential protection for those providing the finance". See also Ferran, above note 3, at p.351; and Romano, ed, Foundations of Corporate Law OUP, 1993), Part IV. Lord Jauncey took the view that such a restriction will be void, and that unless the offending provision is severable the whole contract will fail, so that in the case of a loan contract, the lender will be reduced to a restitutionary remedy to recover the loan. Lord Jauncey's approach to severability was, however, so flexible that it is difficult to see when a restriction will not be severable. In fact the cases considered by Lord Jauncey suggest not that the restriction is void but that it is valid but unenforceable by injunction. The lender will then be able to provide for early repayment or other secondary obligations arising on default. However there will presumably be occasions, for example where there is a threat of insolvency, where the lender needs an injunction to enforce the restriction in order to protect his interest under the contract.

56. See Ferran, above note 3, p.344.

57. The question of conformity with the company's constitution is considered below in connection with the issue of contractual authority. The formal difference between the two cases is that, where a company contract is concerned, the company itself is bound, rather than merely the shareholders individually. Where the company is bound, future shareholders are effectively subject to the restriction, whereas an agreement between particular shareholders outside the articles does not affect future shareholders. Also an injunction can be obtained against the company directly, rather than against the shareholders separately. And in the case of a restriction in a shareholders' agreement (or a restriction in the articles, although this binds the company), the shareholders as a whole will have it in their power to remove the restriction. But in practice a shareholders agreement is likely almost as effectively to obstruct change, at least in companies with a reasonably small and stable body of shareholders (which is the type of company where such an agreement is feasible). If the rationale for the statutory empowering provision is to ensure a degree of flexibility by banning restrictions on shareholders' freedom to make alterations from time to time, the provision should apply equally to shareholders' agreements. If, on the other hand, the statutory provision is correctly understood as enabling, there is no inconsistency with the statute whether the restriction binds the company or the shareholders personally. 
If a company is disabled from accepting a restriction in a contract with an outsider, its contractual capacity is limited. It is clear that there are circumstances where it is advantageous in its dealings with outsiders for a company to be able to accept a restriction on a statutory power, and it is surely better that the company should have the capacity to bind itself, so that, as with other contracts that the shareholders may wish to put beyond the power of directors, the question whether a restriction is binding is dealt with as a question of authority (including the statutory rules adapting this concept to the company) $)^{58}$. It is difficult to see why the law should entirely deny a company the facility to enter into such a contract if it is entered into with due authority ${ }^{59}$.

\section{The authorities}

The proposition endorsed by Lord Jauncey, that a company may not deprive itself of a statutory power by contract with an outsider, is taken to be supported by a line of cases dating from the last century, including Punt v. Symons \& Co Ltd $d^{60}$, Southern Foundries v. Shirlaw ${ }^{61}$, and the more recent case of Cumbrian Newspapers v. Cumberland Herald ${ }^{62}$, although, as has recently been pointed out ${ }^{63}$, it appears to be inconsistent with a couple of other cases, British Murac Syndicate Ltd v. Alperton Rubber Co Ltd ${ }^{64}$ and Baily v. British Equitable Assurance Co. ${ }^{65}$. In Punt v. Symons, the company had entered into a contract with $S$, the managing director of the company, who was also a shareholder, and his executors after his death, by which the company undertook not to alter certain provisions of the articles that gave $S$ or his executors the exclusive right to appoint the directors of the company. After the death of $S$, however, the directors convened a general meeting at which the shareholders voted

58. The issue of contractual authority is considered below.

59. Furthermore, even if the statutory empowering provisions are understood to be mandatory so far as shareholders are concerned, it is strongly arguable that, as in the case of contracts outside the objects, an outsider dealing with the company should be entitled to the protection for his contract that he receives under the rules governing authority, and that he should not be disabled from enforcing his contract by a rule limiting the capacity of the company. The statutory provision that abrogated the ultra vires doctrine (Companies Act 1985 s.35) provides that the capacity of the company is not limited by anything in the company's memorandum; it is not expressed to cover limitations on capacity arising from the statute. This is clearly appropriate where the statute vitiates a contract because it is or may be unfair as between the company and the outsider, as in the case of provisions that impose fiduciary disabilities on directors, e.g. s.322A Companies Act 1985. In the case of a statutory empowering provision, however, even if the provision is understood as mandatory so far as shareholders are concerned, it is not designed to deal with any supposed unfairness as between an outsider and the company, and it is arguably within the rationale of s.35 (if not its expressed scope) that such a provision should not affect the company's capacity with respect to an outsider.

60. [1903] $2 \mathrm{Ch} .506$. There are other cases in which the provision fettering the statutory power is in the articles: Allen v. Gold Reefs of West Africa ([1900] 1 Ch.656), Walker v. London Tramways (12 Ch.D 705), Bushell v. Faith, see above, note 00.

61. [1940] 2 All E.R. 445

62. [1986] 2 All E.R. 816

63. Davenport, above note 3 , at p. 570 .

64. [1915] 2 Ch.186.

65. [1904] 1 Ch.374. See Davenport, above note 3, at pp.560-3. 
to alter these provisions of the articles, and the executors sought an injunction to prevent the company from doing so on the ground that it would be a breach of contract ${ }^{66}$. Byrne J. said ${ }^{67}$ " . . . I am prepared to hold that in the circumstances of the present case the contract could not operate to prevent the article being altered under the provisions of $\mathrm{s.50}$ of the Companies Act $1862^{68}$. . ." 69 .

In Southern Foundries v. Shirlaw the plaintiff had entered into a service contract with the defendant company to act as its managing director. The articles of the defendant were altered after the company was taken over by another company, Federated, to confer on Federated the power to remove a director of the defendant. Federated exercised this power to remove the plaintiff from his directorship, thereby bringing the service contract to an end. For present purposes, the relevant issue was whether the defendant company could alter its articles to confer the power of removal on Federated. There was some doubt whether the service contract actually included an implied term prohibiting the defendant from altering its articles in such a way, but the House of Lords was clear that, if there was such a term, it would not be invalid, and a breach could give rise to damages, but it could not be enforced by injunction against the company ${ }^{70}$. More recently, in Cumbrian Newspapers v. Cumberland Herald, Scott J. also expressed the view that a contract prohibiting the company from altering its articles was enforceable in damages but not by injunction ${ }^{71}$.

These cases appear to give some support to the view that a statutory empowering provision is mandatory, inasmuch as they deny an outside contractor an injunction to enforce a contractual restriction on the exercise of a statutory power (although not to the extent of making the contract void or unlawful or denying a remedy in

66. The executors also argued that the alteration of the articles was contrary to their rights as shareholders, rather than contractors, because the directors had acted for an improper purpose in issuing additional shares for the purpose of procuring the resolution to alter the articles.

67. [1903] 2 Ch.506 at 514.

68. Equivalent to s. 9 Companies Act 1985.

69. However, although the judgement is not entirely clear on this point, it appears that the judge did not consider the contract to be unlawful or void, but merely not enforceable by injunction. After the first passage quoted above, Byrne J. went on to say, at p.514: ". . . It may be that the remedy is in damages only." See also note 80 below.

70. See [1940] A.C. 701, per Viscount Maugham at p. 713, Lord Wright at p.726, Lord Porter at p. 740-1. The other issues decided were that the power under the company's constitution to remove the plaintiff as a director (whether resulting from altered articles or not) did not affect the contractual right of the plaintiff under his fixed term contract, and that the exercise of the power by Federated was attributable to the defendant.

71. [1986] 2 All E.R. 816 at p.830-1. Here the defendant had contracted to give the plaintiff shareholder a right of pre-emption over new share issues and a power to appoint a director, both of which were also incorporated as additional provisions in the articles. By contrast with the approach in Punt v. Symons, Scott J. decided the case by reference to the plaintiff's rights as a shareholder: that is, on the issue whether the additional article conferred class rights or could be altered under s.9. However he then said, obiter, that if the contract purported to prohibit the company from altering its articles so as to cancel these rights, it would not be unlawful or invalid, but it would not be enforceable by injunction against the general meeting preventing it from exercising the power. 
damages for breach of contract) ${ }^{72}$. On the other hand, there are two other cases that have been cited in support of the view that a contract by a company purporting to restrict its exercise of a statutory power is not only valid but also actually enforceable by injunction against the company: British Murac Syndicate Ltd v. Alperton Rubber Co Ltd ${ }^{3}$ and Baily v. British Equitable Assurance Co. ${ }^{74}$. In British Murac, the defendant company had agreed by contract with the plaintiff, a shareholder, that the plaintiff should be entitled to appoint two directors to the defendant's board. A provision to the same effect was inserted in the company's articles as Article 88. The directors of the defendant company then refused to accept the plaintiff's nominations and called a meeting of the shareholders to alter the articles by the deletion of Article 88. Sargant $\mathbf{J}$. awarded a declaration that the plaintiff's nominees were properly appointed directors of the company and an injunction prohibiting the company from calling a general meeting to alter its articles by the deletion of Article 88. This appears to be a clear authority that a contract by the company not to exercise a statutory power in general meeting may be enforced by injunction ${ }^{75}$.

In British Murac Sargant J. relied on the judgements of the Court of Appeal in Baily as authority for his decision ${ }^{76}$. In Baily, the plaintiff had entered into a contract for life insurance with the defendant company. On the view of the facts reached by the Court of Appeal, the contract incorporated By-law 4 of the articles of the company ${ }^{77}$, which provided that the whole profits of the company should be divided between the policy-holders, without deduction (save for expenses). The company then sought to alter the articles to provide, by Article 103, that a proportion of the profits should be retained and credited to a reserve fund before division of the remainder amongst policy-holders. Sargant J. in British Murac understood the case to have held that the company could be enjoined from exercising its statutory power to alter its articles by deleting By-law 4 and introducing Article 103, on the ground that this would be a breach of the contract of life insurance ${ }^{78}$.

It is difficult to arrive at any conclusion consistent with all the cases, certainly if it is necessary to follow the reasoning in the judgements. But it is certainly plausible to interpret the cases as being consistent with the view that a statutory empowering

72. Thus the cases appear to give no support to Lord Jauncey's view in Russell that the restriction is "unlawful" in the sense that its presence can taint the whole contract with illegality and so make it wholly void unless the offending restriction can be severed.

73. [1915] $2 \mathrm{Ch} .186$.

74. [1904] 1 Ch.374.

75. Instead of enforcing an extrinsic contract, the court could have reached this decision by the route later followed by Scott J. in Cumbria Newspapers, of recognising a class right of the plaintiff under the articles. 76. The Court of Appeal decision was overruled in the House of Lords ([1906] A.C. 35), which adopted a different view of the facts.

77. Originally the company was a deed of settlement company with (as a matter of terminology) by-laws rather than articles. The changes to the by-laws were proposed when it converted to a registered company with articles.

78. The House of Lords took a different view of the facts. It held that by-law 4 had never been a term of the plaintiff's policy. The plaintiff was entitled only to the share of the profits determined by the company's practice for the time being: [1906] A.C. 35 at 41-2, per Lord Lindley. 
provision does not prevent a contractual restriction on the exercise of a statutory power from being enforced by injunction, if other factors are taken into account that were not referred to in the cases. First, as mentioned above, if a statutory empowering provision does not preclude the company from accepting a restriction on the exercise of the power, the question arises who has authority, and in what circumstances, to accept such a restriction on behalf of the company; and a restriction might be unenforceable for lack of authority rather than inconsistency with the statute ${ }^{79}$. Secondly (although this may be regarded as an aspect of the issue of authority) it is questionable whether a shareholder should be able to enforce a contract that bears on his position as a shareholder rather than an interest as an outsider, since this would be at odds with the statutory contract to which he is a party. Thirdly, in both Punt and Southern Foundries, the cases that appear to deny the enforceability by injunction of a contractual restriction on alteration, the alteration of the articles that was sought to be enjoined was for this purpose of removing a director, and one can argue that the cases should be distinguished as concerned with this limited issue, rather than the more general issue of conflict with a statutory provision ${ }^{80}$.

\section{The issue of contractual authority}

If a contract by the company accepting a restriction on the exercise of a statutory power is not inconsistent with the statutory empowering provision, the contract may still be ineffective if made without proper authority. Generally a contract will be made by the directors, or by their authority. The articles of the company will normally delegate to the directors "all the powers of the company" 81 . This is usually taken, as a matter of construction, to cover only powers concerned with management of the business, and not powers concerned with relations between shareholders or control

79. On this view the undertaking would be void for all purposes rather than merely unenforceable by injunction. 80. A fourth point might be added. Sometimes where a contract prohibits the alteration of the memorandum or articles the contract can in substance be observed without actually preventing the alteration, but merely treating the company, so far as the outsider is concerned, as if the unaltered provisions still applied. The court might then argue that an injunction to prevent the alteration itself will not be granted because it is not strictly necessary. In Punt v. Symons, having declined to enforce the contract by injunction, the judge suggested (at p.514) that the court might order specific performance of the contract by requiring the company to accept the executors' appointments of directors, without actually concerning itself as to the provision concerning appointments in the articles: " . . . it may be that the stipulation of the contract can be enforced notwithstanding the alteration in the articles." In Baily (where an injunction was in fact granted), it appears that the order made at first instance and affirmed by the Court of Appeal was a declaration "that the company ought to continue to distribute the entire profits. . " without deduction. Although it was accepted by the parties and the court on appeal that the question was whether "the company is at liberty to alter the provisions of By-law 4 . . . in such a manner as to alter the rights of those policyholders to profits" (at p.82), in fact the decision merely recognised the contractual right of the plaintiff to a sum calculated by reference to the whole profits without deduction, irrespective of the terms of the articles for the time being. (There cannot have been any question of a policy-holder's having a proprietary right to any part of the assets of the company). The decision that the terms of the contract incorporated the original By-law 4 was actually compatible with the company's being free to alter its articles. If it altered the articles the company might put itself in the position that the fulfilment of its obligations to policy-holders would disable it from complying with its obligations to shareholders under the articles, but this is a separate matter. See also Ferran, above note 3, at p.355 and Riley, above note 3, at p.40. 81. eg Table A, Article 70 . 
of the general meeting ${ }^{82}$. One might argue that, where a power is vested in the general meeting by statute, it is implicit that authority to accept restrictions on the exercise of the power must be reserved to the general meeting also. But if, as argued above, the statute does not preclude a contract restricting the exercise of the power, there seems to be no reason why the articles should not give authority to the directors to enter into such a contract ${ }^{83}$. If the articles have no express provision on the point, it may be that articles that are expressed to give the directors all the powers of management should be understood to give the directors such authority to be exercised for management purposes, so that directors would have authority to make a contract accepting a restriction on the exercise of a statutory power if the contract has a commercial purpose, for example, to secure finance for the company, but no authority if its purpose is to interfere in the control of the general meeting, for example to assist a prospective bidder for the company's shares ${ }^{84}$.

The concern that directors may bind the company in respect of matters that principally affect the relationship between the shareholders and the company, but may indirectly affect outsiders, is not limited to the exercise of statutory powers. For example, directors might seek to accept restrictions on the power to issue shares or to pay dividends. Here the potential conflict between outsiders' interests and shareholders is the same as in the case of restrictions on the statutory powers, but it cannot be settled by reference to the question whether the contract is inconsistent with a statutory empowering provision, and one would expect it to be settled by reference, broadly, to the issue of authority ${ }^{85}$.

82. Howard Smith v. Ampol Petroleum ([ 1974] A.C.821). The question whether in particular circumstances a contract entered into by directors is within their "powers of management" may also be expressed as the question whether the directors have entered into a contract for a "proper purpose". The question how to determine whether directors have acted for a proper purpose (that is, how to construe the articles, and how to determine what the purpose is of a particular contract entered into by the directors) will not be pursued here. Ferran, above, note 3, at pp.358-361, discusses the proper scope of the directors' authority (and related issues) under the rubric of "constitutional imbalance".

83. The statutory empowering provision might be understood to allow restrictions on the exercise but not to allow arrangements facilitating its exercise, and this would mean that the directors would not have the authority to bind the company positively to exercise the power. Cf Art.25 E.C. Directive 77/91 (2nd Company Law Directive), Q.J. 1977 L26/1.

84. However it would be understandable if the articles were construed, in the absence of express provision, to withhold from the directors the power to accept a restriction on the exercise of a statutory power, even if entered into for a business purpose, on the ground that the principal significance of the power is for issues that primarily affect the shareholders' interests in and control over the company and the directors (i.e. "distributional" and "structural" issues, in the terminology suggested by Eisenberg, above note 1), rather than the management of the company's business.

85. Where a contract is made without authority it is entirely void. Where the directors are outside their actual authority under the proper purpose doctrine, the contract may still be binding on the company under s.35A Companies Act 1985, as amended. The issue in connection with s.35A is likely to be whether the outsider is in good faith. What amounts to lack of good faith is not clear, but it may be that in connection with restrictions on the exercise of a statutory power, first, the outsider would not be in good faith if his motivation for seeking the restriction was not to protect his interests under a contract concerning the company's business, but to interfere in some way with control over the general meeting for its own sake; and, secondly, because the exercise of statutory powers is primarily a matter affecting the shareholders' interests in and control over the company rather than its business, the outsider would be expected to check to see whether the articles include a specific restriction on the directors' authority in this respect, and would be in bad faith if he failed to do so (but see s.35B). 


\section{Agreement by the company with a shareholder}

There is, of course, no general rule precluding a company from contracting with a shareholder. But a shareholder surely cannot make a contract with the company outside the articles that in effect simply varies his rights as a shareholder viz-a-viz the company and other shareholders ${ }^{86}$. If such a contract were enforceable by injunction, it would be tantamount to an alteration of the statutory contract binding on all other shareholders, and to their detriment, without going through the proper procedure for alteration of their respective rights laid down by the statutory contract; and indeed even if the contract were only enforceable by an order for damages, it would seem to be inconsistent with the statutory contract. In such a case, the correct approach is surely for the shareholder to procure the alteration of rights under the statutory contract through the general meeting ${ }^{87}$. This argument is consistent with the outcome in Russell, where the company contract was with the shareholders ${ }^{88}$. However if a shareholder is dealing with the company as an outsider, that is, in relation to the company's business (for example as a lender), and he seeks a restriction on the exercise of a company power pursuant to an interest as an outsider, he should presumably be treated as an outsider ${ }^{89}$.

\section{The issue of removal of a director}

It is also arguable, as mentioned above, that the cases that appear to hold that a company may not bind itself not to exercise a statutory power may be explained by reference to the principle that the power to remove a director cannot be relinquished by the shareholders. This principle has been embodied in a certain form in the statutory

86. Although presumably he could waive rights against the company. In Baily v. British Equitable Assurance Co [1904] 1 Ch.374, at 385, Cozens-Hardy L.J. said (in a different context) " . . . a shareholder must be regarded as an outsider in so far as he contracts with the company otherwise than in respect of his shares". See Davenport, above note 3, at 559.. On the other hand in Allen v. Gold Reefs [1900-3] All E.R. Rep.746, the Court of Appeal accepted that the statutory power of alteration could be displaced by a "special bargain" with a particular shareholder: see per Lindley M.R. at p.748, per Romer L.J. at p.754, and the judges appeared to mean a "special bargain" in an extrinsic contract rather than a class right in the articles. This view is adopted by Gore Browne, ed. Boyle \& Sykes, (Jordans) sec 4.7. See also Ferran, above note 3, at 351-2.

87. There is a problem that a provision in the articles restricting the company from exercising the power might not be enforceable unless it is a class right: see the discussion of class rights above. If this is so, however, it is not clear why it should be possible to circumvent the limitation by way of an extrinsic contract. 88. Similarly in Punt v. Symons, British Murac and Cumbrian Newspapers, the company contract was with a shareholder, and it was not intended to protect an interest of the shareholder as an outsider, for example as a lender, but in effect to bolster his rights as a shareholder. Thus the argument would indicate that the contract should be unenforceable and the court should instead have based his protection on his rights under the statutory contract. Where all the shareholders are party to the agreement, it may be possible to argue, following Cane v. Jones [1980] 1 W.L.R. 1451 that the shareholders' agreement actually amounts to an alteration of the articles.

89. It might be better to say that under the statutory contract the directors do not have the authority to enter into a contract with a shareholder concerning his rights under the statutory contract (and that the shareholder as a party to the contract will be bound by this restriction on the directors' authority in any dealing with the directors). 
provision now in $5.303^{90}$, but the provision was not in force at the time of the cases ${ }^{91}$. However one can argue that the principle received tacit recognition, to some degree, in the judicial treatment of the issue before the enactment of the provision.

There are two issues that arise on the removal of a director. The first is whether the requisite power of removal exists under the company's constitution or by statute. The second is the effect on the director's appointment of an extrinsic contract for example, a service contract with the director, or a contract with an outsider conferring a right of appointment, or a shareholders' agreement concerning a directorship. It appears that, with regard to the first issue, aside from s.303, the company has no power to remove a director except in accordance with a provision of the articles providing for removal, so that (before the provision in $\mathrm{s.} 303$ was enacted) to remove a director in the absence of a pre-existing provision for removal required an alteration of the articles to create such a power ${ }^{92}$. With regard to the second issue, again considering the position before the enactment of the provision in s.303, it appears that if the removal was effective under the company's constitution, but in breach of a service contract with the director, the director could not obtain an injunction requiring the company to remedy the breach by restoring him to the position of director (by going through the appropriate procedure under the constitution), but could only recover damages ${ }^{33}$. S.303, in addition to conferring a power of removal by ordinary resolution under the constitution, confirms that a service contract cannot be enforced by injunction to frustrate a removal under the section.

Punt and, on one view, Southern Foundries, were cases where, for the purpose of securing a director against removal under the constitution (with respect to the first issue above), a contract with the company purported to prohibit the company from altering provisions of its articles. Instead of invoking a general rule that the company may not by contract restrict itself in the exercise of a statutory power, these cases may be satisfactorily explained on the basis that an injunction to prevent alteration of the articles will be denied in the particular case where the alteration is necessary to create a power of removal (with reference to the first issue above). An injunction

90. See above, text following note 29.

91. There is now also a provision that invalidates a service contract for more than five years unless it has been approved by the general meeting: s.319 Companies Act 1985.

92. Imperial Hydropathic Hotel Compny v. Hampson (1882) 23 Ch.D. 1 Southern Foundries v. Shirlaw [1940] A.C. 701; Gower, p.153. Imperial Hydropathic establishes also that a director can personally enforce by declaration or injunction his right to be recognised as such until a proper removal is carried out under the constitution, whether or not he is himself a shareholder. This is curious inasmuch as it means that a director not party to the statutory contract is permitted to rely on its terms, rather than having to depend on a shareholder enforcing the terms of the statutory contract. However the position would be intolerable if a director could not take action himself to establish his status in the event of a dispute between directors and particular shareholders, and if shareholders had to be alert to take action to protect the appointment of directors against purported removals. The position may be summarised by saying that a director, qua director, is an office-holder rather than an employee or agent, and therefore entitled to secure his office by injunction: cf Malloch v. Aberdeen Corporation [1971] All E.R. 1278 at 1294, where Lord Wilberforce distinguished "pure master and servant cases" from a case where there is something "in the nature of an office or a status" (actually with reference to the availability of natural justice). 93. Southern Foundries v. Shirlaw [1940] A.C. 701 
is denied because the director should not be able to secure himself from removal by contract in this way.

The argument above has been simply that the cases that have been relied upon in support of a general rule that the company cannot by contract deprive itself of a statutory power may instead be accounted for by reference to a much narrower rule concerning the removal of directors, for which there is some independent support. S.303 extended the rule by creating a power of removal that could not be ousted by contrary provisions of the articles, as well as confirming that the power of removal could not be frustrated by an extrinsic service contract ${ }^{94}$. It is worth considering briefly the scope and rationale of this narrower rule, as a mandatory rule of company law (to be contrasted with the enabling provisions conferring powers of alteration of the memorandum and articles). One would normally expect the appointment of a fiduciary to be expressly revocable at any time because of the power wielded by the fiduciary and the danger of abuse. To the extent that a mandatory rule overrides an appointment in the articles, the rationale seems to be simply that shareholders have to be protected against their own rashness, or failure to consider the long term, in committing themselves to a certain director. There are arguably stronger grounds for a mandatory rule if the directors themselves are involved in arranging the directorship: for example where they recommend an appointment, or where they grant a service contract, which, if enforceable by injunction, would amount to an appointment. Here it may be argued that the shareholders should be able to procure a removal to obviate the danger of exploitation by directors ${ }^{95}$. It is arguable also that restrictions on the removal of directors is against the public interest (as opposed to the private interest of the company's shareholders) because it tends to frustrate takeovers, which are (or may be) in the public interest ${ }^{96}$.

There are certain situations where the scope of s.303 and the underlying common law may be in issue. S. 303 provides expressly that where a director has a service contract with the company it cannot be enforced by injunction to frustrate a power of removal. But the section says nothing about the case where the director holds office

94. The rule against enforcement by injunction of a director's service contract is sometimes understood as an application of the general rule that an injunction is not available to enforce a contract for the provision of personal services. The status and scope of this rule are controversial. It is arguable that non-enforcement by injunction is based not on a rule of law but on a rebuttable presumption that a breakdown in relations has made it impossible in practice for the contract to be performed: see Hill v. Parsons [1972] Ch.305, Powell v. London Borough of Brent [1987] I.R.L.R. 466, Harvey on Industrial Relations and Employment Law, ed. Perrins, para A178, Smith \& Wood, Industrial Law (Butterworths, Sth ed.) p.271. A shareholders' resolution (or a board resolution) removing a director does not necessarily imply any breakdown in relations between the director and those, if anyone, with whom he has to maintain satisfactory personal relations in order to perform his service contract. It may be better to regard the director's position as governed by a specific mandatory company law rule. The rule against enforcing service contracts would not apply to an extrinsic agreement granting a power of appointment.

95. This would be an application of the "opportunistic amendment hypothesis" for the justification of a "power allocating" mandatory rule, in Gordon, above note 14, a p.1568.

96. See Farrar, p.606; Bradley (1990) 53 M.L.R. 170; Easterbrook \& Fischel, above note 13, at pp. 166-174. 
under a power of appointment given to an outsider by contract, which was the situation in Punt and in British Murac. However the corresponding Australian provision? provides that where a director represents a debenture-holder, his removal by ordinary resolution does not take effect until a replacement is appointed by the debentureholder. Thus the provision of the debenture giving a power of appointment appears to be enforceable by injunction, although not to secure a particular director against removal. In this situation, first, the company has a strong commercial interest in being able to make a contract that the outsider can enforce by injunction, since this form of enforcement is indispensible if this type of contract is to be viable at all; and, secondly, there is no risk of substantial loss of control over the management as a whole, or of exploitation by directors, and so a curtailing of the principle of exclusive control over directorships by the general meeting is justified ${ }^{98}$. However one would expect the position to be different if a contract purported to give an outsider by contract the power to appoint the majority or even a substantial proportion of the directors. It is worth noting that in Punt, where the outsider's right of appointment was not enforced by injunction, the contract purported to confer a right to appoint all the directors, whereas in British Murac, where an injunction was granted, the contract purported to confer only the right to appoint one or two directors as representatives 99 .

Neither $\mathbf{3 0 3}$ nor any case law predating it deals with the case where a shareholders' agreement prohibits the shareholders from voting to remove a director. Is such a contract also unenforceable by injunction? The principle behind the section suggests that such an agreement should be unenforceable, but the section explicitly overrides an agreement between shareholders entrenching directors only in the form of a provision of the articles. The issue has risen, implicitly, in the cases concerning quasi-partnership companies where the shareholders have established the company on the understanding that they will be permanent directors'. On the narrow approach to statutory interpretation adopted in Bushell v. Faith, a court might well conclude that, whatever its rationale, s.303 fails to cover a shareholders' agreement ${ }^{2}$. However the approach seems to have been that $\mathrm{s.303}$ does invalidate such an agreement, but that, if the power is exercised to remove from his directorship a shareholder who had a "legitimate expectation" to remain as director, the shareholder will be entitled,

\section{Companies Act 1981 (Cth) s.221(5)}

98. Whereas, on the other hand, damages are a tolerable if imperfect remedy for loss of a service contract, and if all service contracts were enforceable by injunction there would be a risk of substantial loss of control. 99. See Gore Browne, sec.4.7. Similarly it must be doubtful whether a management contract purporting to give an outside body full and exclusive powers of management is enforceable by injunction. In Lee Panavision v. Lee Lighting [1991] BCC 610 such an agreement was unenforceable for other reasons; Jaffey (1994) 15 Co. Law. 22.

1. In fact these cases are not usually approached on the explicit basis that there is a shareholders' agreement providing for permanent directors, but that in the circumstances the shareholder has a "legitimate expectation" to remain as director - although this legitimate expectation arises from the dealings between the shareholders, and so is really tantamount to an implicit shareholders' agreement.

2. Se above, text following note 29 . This would mean that the agreement could be enforced to prevent voting on a resolution to exercise the statutory power of removal. 
under the court's jurisdiction to protect against minority oppression, to be bought out or possibly have the company wound up ${ }^{3}$. The case where, as in a partnership, the shareholders establish the company with a view to exploiting both their capital and their management expertise is another example of a situation where the mandatory rule allowing a shareholder voting majority to remove a director has to be curtailed, not in this case to facilitate the company's dealings with outsiders, but to encourage the establishment of such companies in the first place ${ }^{4}$.

\section{SUMMARY}

It is important to establish whether provisions of the Companies Act that confer powers on the company are intended to be mandatory in the sense that they deny shareholders the freedom to exclude or restrict the exercise of the power. The best interpretation of the statutory provisions that provide for the alteration of the memorandum or articles is that they do not deny shareholders this freedom. This means in particular that neither a shareholders' agreement restricting voting on the exercise of such a statutory power, nor an agreement by the company not to exercise the power, is inconsistent with or invalidated by the statutory empowering provision. However there may well be other grounds for holding such agreements unenforceable, and arguably the presence of such grounds explains the decisions (including the recent decision in Russell) that appear to hold that an agreement by the company not to exercise a statutory power is inconsistent with the statutory empowering provision.

The statutory provisions concerning alteration of the memorandum or articles are to be distinguished from the provision of s. 303 concerning removal of a director, the whole purpose of which is to confer a power that is incapable of being excluded or restricted by contrary agreement. Since s. 303 was clearly intended to be mandatory in this sense, it seems to be a flaw in the drafting of the provision that it does not expressly stipulate the shareholder voting rights that are to apply on its exercise, and this flaw was exposed in Bushell v. Faith.

3. Under s.459 or under the "just and equitable winding up" jurisdiction under s.122(1)(g) Insolvency Act 1986; e.g. Ebrahimi v. Westbourne Galleries [1973] A.C. 360, Re Bird Precision Bellows [1985] 3 All E.R. 523; see Gower, p.154.

4. Easterbrook and Fischel, above note 13, p.235. 